\title{
Leaf blight and defoliation caused by two new pathovars of Xanthomonas axonopodis on Schinus terebinthifolius and Mabea fistulifera
}

\author{
H. G. M. Ferraz ${ }^{a}$, L. M. S. Guimarães ${ }^{a}$, J. L. Badel ${ }^{a}$, M. R. Tótola ${ }^{b}$ and A. C. Alfenas ${ }^{a *}$ \\ ${ }^{a}$ Department of Phytopathology, Universidade Federal de Viçosa, Viçosa, MG 36570-000; and ' Department of Microbiology, Universidade \\ Federal de Viçosa, Viçosa, MG 36570-000, Brazil
}

Schinus terebinthifolius and Mabea fistulifera have been used for forest repositioning and urban forestry in Brazil. In October 2012, in a routine inspection at the research nursery of the Forestry Department of the Universidade Federal de Viçosa, in Minas Gerais, Brazil, a mortality of approximately $40 \%$ of the seedlings was observed as a result of diseases characterized by leaf blight and intense defoliation, which culminated in the death of the plants. Microscopy observations revealed oozing from the infected tissue and isolations revealed a bacterial aetiology for both diseases. Bacterial cells that formed bright yellow mucoid colonies with round edges were routinely isolated from lesion margins. Inoculation of isolated strains into healthy seedlings reproduced the symptoms observed under natural conditions. Bacterial cells showing the same morphological, biochemical and molecular characteristics as those originally isolated from naturally infected plants were reisolated from inoculated plants. Morphological, physiological and biochemical tests as well as $16 \mathrm{~S}$ rDNA sequencing and multilocus sequence analysis using four housekeeping genes, dnaK, fyuA, gyrB and $r p o D$, confirmed the newly isolated strains belong to Xanthomonas axonopodis. Plant cross-inoculations showed the strains did not belong to any known phylogenetically related pathovar. Pathovars X. axonopodis pv. schini pv. nov. and X. axonopodis pv. mabeae pv. nov. are proposed as the causal agents of bacterial leaf blight on S. terebinthifolius and M. fistulifera, respectively.

Keywords: bacterial disease, fatty acid profiling, housekeeping genes, metabolic fingerprinting, multilocus sequence analysis

\section{Introduction}

Schinus terebinthifolius and Mabea fistulifera are trees native to Brazil. Schinus terebinthifolius is also native to Argentina, Paraguay and Uruguay. However, both trees have been introduced in tropical and subtropical areas around the world (Ewe \& Sternberg, 2002). In Florida and Hawaii, S. terebinthifolius was introduced as an ornamental plant and has become one of the most aggressive invasive species (Ewe \& Sternberg, 2002; Williams et al., 2005). In Brazil, S. terebinthifolius is known as aroeirinha, aroeira da praia, aroeira negra, aroeira vermelha, aroeira de Minas and corneiba. In the United States, it is known as Brazilian peppertree and Florida holly (Morton, 1978). It is used mainly in urban forestry as an ornamental plant and in forest repositioning. Its pink/red seeds are used as a condiment due to their mild and slightly spicy flavour, and the seeds have also been used as anti-inflammatory, antipyretic, analgesic and cleansing agents (Carvalho et al., 2013). Mabea

*E-mail: aalfenas@ufv.br

Published online 9 April 2017 fistulifera occurs widely in the Brazilian Cerrado and in transition areas of semideciduous forests in the states of Rio de Janeiro, Minas Gerais and São Paulo. It is an undemanding species that grows well in low-fertility soils and could be used in the recovery of degraded areas where recolonization is facilitated by several animal species that serve as potential dispersers of plant species (Leal Filho \& Borges, 1992).

In October 2012, in a routine inspection at the Research Nursery of the Forestry Department of the Universidade Federal de Viçosa, in Minas Gerais, Brazil, approximately $40 \%$ of the seedlings of $S$. terebinthifolius and $M$. fistulifera were dying as a result of diseases characterized by leaf blight and intense defoliation. Previous reports indicated that $S$. terebinthifolius can be an alternative host for Xanthomonas campestris pv. viticola, which is the causal agent of grapevine canker (Peixoto et al., 2007), and Xanthomonas axonopodis pv. mangiferaindicae, which is the causal agent of mango bacterial black spot (Pruvost et al., 1992). One study has also reported that Enterobacter cowanii causes leaf spot on M. fistulifera (Furtado et al., 2012).

The identification of Xanthomonas species has been based primarily on morphological, physiological and biochemical characteristics (Van den Mooter \& Swings, 1990; Schaad et al., 2001). However, these conventional 
methods are not adequate for distinguishing between pathovars of xanthomonads (Dye, 1962). Significant progress in the taxonomy of xanthomonads has been achieved with the use of DNA-DNA reassociation techniques (Vauterin et al., 1995). The study by Vauterin et al. (1995) resulted in the recognition of 20 Xanthomonas species. Additionally, eight species of xanthomonads have been reclassified, including X. cynarae (Trébaol et al., 2000), X. euvesicatoria, X. gardneri, X. perforans (Jones et al., 2004) and X. dyei (Young et al., 2010). Additional newly reclassified xanthomonads include $X$. fuscans, X. fuscans subsp. fuscans, X. fuscans subsp. aurantifolii, X. alfalfae, $X$. alfalfae subsp. alfalfae, X. alfalfae subsp. citrumelonis and Xanthomonas citri subsp. malvacearum (Schaad et al., 2006). Currently, various other molecular techniques, such as $16 \mathrm{~S}$ rDNA sequencing (Hauben et al., 1997), repetitive sequence-based PCR (rep-PCR), enterobacterial repetitive intergenic consensus sequence (ERIC) PCR, box sequences (BOX) PCR (Rademaker et al., 2005) and multilocus sequence analysis (MLSA; Almeida et al., 2010; Young et al., 2008) are used in phylogenetic studies of xanthomonads. Among these techniques, MLSA, which is based on sequencing several housekeeping genes, has been widely used for delimitation of plant pathogenic bacterial species (Young et al., 2008, 2010; Ah-You et al., 2009; Samanta et al., 2013). MLSA is a simple method for rapidly and accurately allocating strains in their corresponding species within the genus, which reflects their allocation based on DNA-DNA reassociation (Young et al., 2008). The objective of this study was to identify the causal agents responsible for bacterial leaf blight of $S$. terebinthifolius and M. fistulifera. The results indicated that bacteria belonging to two new pathovars of $X$. axonopodis were responsible for these diseases.

\section{Materials and methods}

\section{Disease symptoms and bacterial isolation, cultivation and storage}

Naturally infected tissue of plants growing in a nursery was collected from both host species between October and November of 2012. Microscopic oozing from leaf fragments $(0.5 \times 0.5 \mathrm{~cm})$ collected from the lesion margins and placed on a drop of water was observed under a light microscope $(\times 200)$. Samples showing bacterial oozing were disinfected in $50 \%$ ethanol and then in sodium hypochlorite containing $2 \%$ chlorine. After $3 \mathrm{~min}$, the fragments were rinsed in sterile distilled water and then macerated in saline solution $(0.85 \% \mathrm{NaCl})$. Loops of the macerate were streaked onto solid 523 medium (Kado \& Heskett, 1970), and the plates were incubated at $28{ }^{\circ} \mathrm{C}$ in the dark. After $24-48 \mathrm{~h}$ of incubation, individual yellow colonies were transferred to fresh solid 523 medium. Purified cultures were maintained on medium 523 at $4{ }^{\circ} \mathrm{C}$ and stored in $30 \%$ glycerol at $-80{ }^{\circ} \mathrm{C}$ for later use.

\section{Pathogenicity tests}

Sixty-day-old seedlings of S. terebinthifolius and M. fistulifera were transplanted to $2 \mathrm{~L}$ plastic bags containing Carolina Soil substrate $(70 \%$ sphagnum, $20 \%$ roasted rice straw, $10 \%$ perlite; Carolina Soil do Brasil), enriched with superphosphate $\left(6 \mathrm{~kg} \mathrm{~m}^{-3}\right)$ and Osmocote (19:6:10 at $1.5 \mathrm{~kg} \mathrm{~m}^{-3}$; Scotts Australia Pty Ltd). Plants were maintained in a greenhouse and fertilized every 2 weeks with $100 \mathrm{~mL}$ of a $7.5 \mathrm{~g} \mathrm{~L}^{-1}$ Ouro Verde solution $\left(15 \% \mathrm{~N}, 15 \% \mathrm{P}_{2} \mathrm{O}_{5}, 20 \% \mathrm{~K}_{2} \mathrm{O}\right)$ at $6 \mathrm{~g} \mathrm{~L}^{-1}$ per plant.

The seedlings were inoculated 30 days after transplanting. Cultures were grown on solid 523 medium at $28{ }^{\circ} \mathrm{C}$ for $48 \mathrm{~h}$ in the dark. Five seedlings were separately spray inoculated with

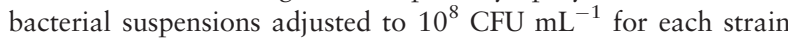
(Table 1). The inoculum was evenly sprayed on both sides of the leaves before reaching the surface run-off point. Following inoculation, the plants were incubated in a moist chamber at $25^{\circ} \mathrm{C}$ for $24 \mathrm{~h}$ and subsequently maintained in a greenhouse (temperature $20 \pm 5{ }^{\circ} \mathrm{C}$ and relative humidity $75 \pm 5 \%$ ). The pots were irrigated daily using tap water. Seedlings sprayed with sterile distilled water served as controls.

\section{S rDNA amplification and sequencing}

DNA was extracted from bacterial cultures grown in liquid 523 medium at $28{ }^{\circ} \mathrm{C}$ for $48 \mathrm{~h}$ in the dark using the Wizard Genomic DNA purification kit (Promega) according to the manufacturer's instructions. The $16 \mathrm{~S}$ rDNA gene region was amplified by PCR using primers $\mathrm{fd} 2\left(5^{\prime}\right.$-AGAGTTTGATCCTGGCTCAG$\left.3^{\prime}\right)$ and rP1 (5'-ACGGTTACCTTGTTACGACTT-3') (Weisburg et al., 1991). PCRs were performed in a $25 \mu \mathrm{L}$ reaction containing $12.5 \mu \mathrm{L}$ of Dream Taq PCR Master Mix $2 \times$ (MBI Fermentas), $1.5 \mu \mathrm{L}$ of each primer $(10 \mu \mathrm{M})$ and $2 \mu \mathrm{L}$ of genomic DNA (10 $\left.\mathrm{ng} \mu \mathrm{L}^{-1}\right)$. Amplification was performed with an initial denaturation at $94^{\circ} \mathrm{C}$ for $2 \mathrm{~min}$; then 35 cycles of $94{ }^{\circ} \mathrm{C}$ for $30 \mathrm{~s}, 52^{\circ} \mathrm{C}$ for $30 \mathrm{~s}, 72{ }^{\circ} \mathrm{C}$ for $2 \mathrm{~min}$; and a final extension at $72{ }^{\circ} \mathrm{C}$ for $5 \mathrm{~min}$. The expected amplicon size was confirmed by agarose gel electrophoresis using $5 \mu \mathrm{L}$ of PCR product. Fragments of the expected size were purified with the illustra GFX PCR DNA and Gel Band Purification kit (GE Healthcare). Sequencing was performed in a 3500XL Series Genetic Analyzer (Applied Biosystems) using the same primers used for PCR amplification. Subsequently, the sequences were compared with sequences available in GenBank (http://www.ncbi.nlm.nih.gov) using BLAST.

\section{Biochemical and physiological tests}

The strains were subjected to the following tests in the Laboratory Guide for Identification of Plant Pathogenic Bacteria (Schaad et al., 2001): (i) Gram typing using Ryu's non-staining $\mathrm{KOH}$ test; (ii) formation of yellow colonies on yeast extract-dextrose-calcium carbonate agar medium (YDC); (iii) oxidase activity; (iv) starch hydrolysis; (v) catalase activity; (vi) gelatin liquefaction; (vii) $\mathrm{H}_{2} \mathrm{~S}$ production from cysteine; (viii) esculin hydrolysis; (ix) urease activity; (x) nitrate reduction; (xi) utilization of asparagine as a sole source of carbon and nitrogen; (xii) anaerobic growth; (xiii) production of fluorescent pigment on solid King's B medium; and (xiv) xanthomonadin production.

\section{Metabolic fingerprinting}

Strains were tested for their ability to utilize carbon sources using the Biolog GN microtitre plate system (Microlog 2, v. 3.5; Biolog Inc.). A single colony from cultures grown on nutrient agar (NA) medium (Difco) was transferred to trypticase soy agar (TSA) medium and incubated at $28^{\circ} \mathrm{C}$ for $24 \mathrm{~h}$. Bacterial 
Table 1 Xanthomonas strains used in multilocus sequence analysis

\begin{tabular}{|c|c|c|c|c|c|c|}
\hline \multirow[b]{2}{*}{ Bacterial strain } & \multirow[b]{2}{*}{ Species } & \multirow[b]{2}{*}{ Synonym } & \multicolumn{4}{|c|}{ GenBank accession number } \\
\hline & & & dnak & fyuA & gyrB & $r p o D$ \\
\hline ICMP $196^{a}$ & Xanthomonas albilineans & & - & - & EU498963 & EU499082 \\
\hline ICMP $35^{\mathrm{a}}$ & $X$. arboricola pv. juglandis & & EU498750 & EU498852 & EU498951 & EU499070 \\
\hline ICMP $50^{\mathrm{a}}$ & X. axonopodis pv. axonopodis & & EU498751 & EU498853 & EU498952 & EU499071 \\
\hline ICMP $5718^{b}$ & $X$. axonopodis pv. alfalfae & X. alfalfae subsp. alfalfae & EU498792 & EU498894 & EU499001 & EU499120 \\
\hline ICMP 4765 & X. axonopodis pv. alfalfae & X. alfalfae subsp. alfalfae & EU498788 & EU498890 & EU498997 & EU499116 \\
\hline ICMP 8432 & X. axonopodis pv. aurantifolii & X. fuscans subsp. aurantifolii & EU498811 & EU498913 & EU499027 & EU499146 \\
\hline ICMP $194^{\mathrm{b}}$ & X. axonopodis pv. begoniae & & EU498757 & EU498859 & EU498962 & EU499081 \\
\hline ICMP $444^{\mathrm{b}}$ & X. axonopodis pv. cajani & & EU498767 & EU498869 & EU498973 & EU499092 \\
\hline ICMP $24^{\mathrm{a}}$ & X. axonopodis pv. citri & $X$. citri subsp. citri & EU498749 & EU498851 & EU498950 & EU499069 \\
\hline ICMP 10009 & X. axonopodis pv. citrumelo & X. alfalfae subsp. citrumelonis & EU498826 & EU498926 & EU499042 & EU499162 \\
\hline ICMP 10010 & X. axonopodis pv. citrumelo & X. alfalfae subsp. citrumelonis & EU498827 & EU498927 & EU499043 & EU499163 \\
\hline ICMP10014 & X. axonopodis pv. citrumelo & X. alfalfae subsp. citrumelonis & EU498828 & EU498928 & EU499044 & EU499164 \\
\hline ICMP $5732^{b}$ & X. axonopodis pv. glycines & & EU498794 & EU498896 & EU499003 & EU499122 \\
\hline ICMP 217 & X. axonopodis pv. malvacearum & X.citri subsp. malvacearum & EU498760 & EU498862 & EU498966 & EU499085 \\
\hline ICMP $5741^{\mathrm{b}}$ & X. axonopodis pv. manihotis & & EU498796 & EU498898 & EU499006 & EU499125 \\
\hline ICMP $5834^{b}$ & X. axonopodis pv. phaseoli & X. phaseoli & EU498802 & EU498904 & EU499015 & EU499134 \\
\hline ICMP 239a & X. axonopodis pv. phaseoli biovar fuscans & X. fuscans subsp. fuscans & EU498761 & EU498863 & EU498967 & EU499086 \\
\hline ICMP 3031 & X. axonopodis pv. ricini & & EU498782 & EU498884 & EU498991 & EU499110 \\
\hline ICMP $5757^{b}$ & X. axonopodis pv. vasculorum & & EU498798 & EU498900 & EU499011 & EU499130 \\
\hline ICMP $333^{\mathrm{b}}$ & X. axonopodis pv. vignicola & & EU498764 & EU498866 & EU498970 & EU499089 \\
\hline ICMP $109^{\mathrm{a}}$ & X. axonopodis pv. vesicatoria & X. euvesicatoria & EU498754 & EU498856 & EU498955 & EU499074 \\
\hline ICMP 1663 & X. axonopodis pv. vesicatoria & X. euvesicatoria & EU498777 & EU498879 & EU498986 & EU499105 \\
\hline ICMP 4739 & X. axonopodis pv. vesicatoria & X. euvesicatoria & EU498790 & EU498892 & EU498999 & EU499118 \\
\hline ICMP 8037 & X. axonopodis pv. vesicatoria & X. euvesicatoria & EU498810 & EU498912 & EU499026 & EU499145 \\
\hline ICMP $12545^{\mathrm{a}}$ & X. bromi & & EU498837 & EU498937 & EU499052 & EU499172 \\
\hline ICMP $13^{\mathrm{a}}$ & X. campestris pv. campestris & & EU498747 & EU498849 & EU498948 & EU499067 \\
\hline ICMP $204^{\mathrm{a}}$ & X. cassavae & & EU498759 & EU498861 & EU498965 & EU499084 \\
\hline ICMP $9513^{a}$ & X. codiaei & & EU498822 & EU498922 & EU499038 & EU499158 \\
\hline ICMP $2415^{\mathrm{a}}$ & X. dyei pv. dysoxyli & & EU498781 & EU498883 & EU498990 & EU499109 \\
\hline ICMP $5715^{\mathrm{a}}$ & $X$. frageriae & & EU498791 & EU498893 & EU499000 & EU499119 \\
\hline ICMP 16689a & X. gardneri & & EU498843 & EU498943 & EU499058 & EU499178 \\
\hline ICMP $453^{\mathrm{a}}$ & X. hortorum & & EU498769 & EU498871 & EU498975 & EU499094 \\
\hline ICMP $189^{a}$ & $X$. hyacinthi & & - & - & EU498960 & EU499079 \\
\hline ICMP 8683 & $X$. melonis & & EU498816 & EU498916 & EU499032 & EU499152 \\
\hline ICMP $3125^{\mathrm{a}}$ & X. oryzae pv. oryzae & & EU498784 & EU498886 & EU498993 & EU499112 \\
\hline ICMP $16690^{\mathrm{a}}$ & $X$. perforans & & EU498844 & EU498944 & EU499059 & EU499179 \\
\hline ICMP $570^{\mathrm{a}}$ & $X$. pisi & & EU498770 & EU498872 & EU498976 & EU499095 \\
\hline ICMP $5816^{\mathrm{a}}$ & X. populi & & EU498801 & EU498903 & EU499014 & EU499133 \\
\hline ICMP $16916^{a}$ & X. sacchari & & - & - & EU499063 & EU499183 \\
\hline ICMP $6774^{\mathrm{a}}$ & X. theicola & & - & - & EU499020 & EU499139 \\
\hline ICMP $5752^{\mathrm{a}}$ & X. translucens pv. translucens & & - & - & EU499009 & EU499128 \\
\hline ICMP $3103^{a}$ & X. vasicola & & EU498783 & EU498885 & EU498992 & EU499111 \\
\hline ICMP $63^{\mathrm{a}}$ & X. vesicatoria & & EU498753 & EU498855 & EU498954 & EU499073 \\
\hline LPF 603 & X. axonopodis (Schinus terebinthifolius) & & KY205644 & KY205653 & KY273415 & KY273424 \\
\hline LPF 604 & X. axonopodis (S. terebinthifolius) & & KY205645 & KY205654 & KY273416 & KY273425 \\
\hline LPF 605 & X. axonopodis (S. terebinthifolius) & & KY205646 & KY205655 & KY273417 & KY273426 \\
\hline LPF 606 & X. axonopodis (S. terebinthifolius) & & KY205647 & KY205656 & KY273418 & KY273427 \\
\hline LPF 607 & X. axonopodis (Mabea fistulifera) & & KY205648 & KY205657 & KY273419 & KY273428 \\
\hline LPF 608 & X. axonopodis (M. fistulifera) & & KY205649 & KY205658 & KY273420 & KY273429 \\
\hline LPF 609 & $X$. axonopodis (M. fistulifera) & & KY205650 & KY205659 & KY273421 & KY273430 \\
\hline LPF 610 & $X$. axonopodis (M. fistulifera) & & KY205651 & KY205660 & KY273422 & KY273431 \\
\hline LPF 611 & $X$. axonopodis (M. fistulifera) & & KY205652 & KY205661 & KY273423 & KY273432 \\
\hline ICMP $17033^{a}$ & Stenotrophomonas maltophilia & & EU498848 & - & EU499066 & EU499186 \\
\hline
\end{tabular}

a Type strain of species.

${ }^{b}$ Pathotype strain. 
colonies were harvested with a moistened sterile cotton swab suspended in sterile saline solution, and the optical density at $590 \mathrm{~nm}$ was adjusted to match the Biolog GN MicroPlate system's turbidity standards. Then, $150 \mu \mathrm{L}$ of bacterial suspensions were pipetted into the wells of the microplates. Reactions were rated as positive or negative $72 \mathrm{~h}$ after incubation of the Biolog GN plates at $28^{\circ} \mathrm{C}$.

\section{Fatty acid profiling}

Whole cell fatty acid methyl ester (FAME) profiles were determined using the Microbial Identification System (MIS; MIDI Inc.). Bacterial strains were grown on TSA medium at $28{ }^{\circ} \mathrm{C}$ for 1 day. Fatty acids were extracted following the procedures described in the MIS Handbook and analysed with a 7890 gas chromatograph (Hewlett Packard). Fatty acid identification and quantification were automatically provided by the MIS software by comparison with internal FAME standards. Fatty acid profiles were compared to reference strains deposited in the MIS database, and an index that expressed the similarity of profiles of the test strains with profiles of known Xanthomonas species and pathovars deposited in the database were generated.

\section{Multilocus sequence analysis}

Phylogenetic analyses were performed using the four housekeeping genes dnaK, fyuA, gyrB and rpoD (Young et al., 2008). The reaction mixture used for PCR was the same as for amplification of the $16 \mathrm{~S}$ rDNA region, except for the sequence of the primers (Young et al., 2008). PCR amplifications were performed with initial denaturation at $94{ }^{\circ} \mathrm{C}$ for $3 \mathrm{~min}$; 30 cycles of $94{ }^{\circ} \mathrm{C}$ for $30 \mathrm{~s}, 52{ }^{\circ} \mathrm{C}$ for $30 \mathrm{~s}, 72{ }^{\circ} \mathrm{C}$ for $1 \mathrm{~min}$; and final extension at $72{ }^{\circ} \mathrm{C}$ for $10 \mathrm{~min}$. Confirmation of amplicon sizes, amplicon purification and sequencing was conducted as described above.

Two phylogenetic analyses were performed. In the first analysis, nucleotide sequences of genes $d n a K, f y u A, g y r B$ and $r p o D$ of strains used in this study as well as sequences of the same four genes obtained from validly published Xanthomonas species (Bull et al., 2010, 2012) were used. In the second analysis, only nucleotide sequences of $X$. axonopodis pathovars were used. Nucleotide sequences not determined in this study and used in both phylogenetic analyses were obtained from GenBank (Table 1). In this study, the Xanthomonas classification and nomenclature proposed by Vauterin et al. (1995) was adopted.

Maximum parsimony (MP) and Bayesian inference (BI) methods were used to construct phylogenetic trees. Analyses were conducted using the concatenated nucleotide sequences of the dnaK, fyu $A$, gyrB and $r p o D$ genes. Maximum parsimony analysis was performed using PAUP* v. $4.0 \mathrm{~b} 10$ using a heuristic search with the TBR (tree bisection reconnection) algorithm to switch the branches. Nucleotide sequences were added randomly by a stepwise method with 100 repetitions. Branch stability was assessed by bootstrap with 1000 replications. Bayesian inference was performed with MRBAYES v. 3.1.2 (Ronquist \& Huelsenbeck, 2003). The substitution model was selected based on the Akaike information criterion (AIC) using MRMOdelTeST v. 3.2. The probability of a posteriori tree distribution was calculated using MCMCMC (Metropolis-coupled Markov chain Monte Carlo) of two chains from a random tree with 10 million generations and discarding $25 \%$ of the first trees. The MCMCMC convergence and effective sample size were examined using the TRACER v. 1.4 program. Phylogenetic trees were viewed and edited with FIGTREE v. 1.3.1. (http://tree.bio.ed.ac.uk/software/figtree).

\section{Plant cross-inoculation with $X$. axonopodis pathovars}

Cross-inoculation of host plants was performed with pathovars of $X$. axonopodis that were phylogenetically more closely related to the strains isolated from $S$. terebinthifolius and $M$. fistulifera in this study. Cross-inoculations were conducted using representative and designated type strains $X$. axonopodis pv. schini LPF 603 and X. axonopodis pv. mabeae LPF 607. Based on the results of MLSA, strain LPF 603 was inoculated onto plants of cassava (Manihot esculenta), common bean (Phaseolus vulgaris) and M. fistulifera. Strain LPF 607 was inoculated onto sweet pepper (Capsicum annuum), castor bean (Ricinus communis) and S. terebinthifolius. Representative strains of X. axonopodis pv. manihotis (IBSBF $278=\mathrm{ICMP} 5741=\mathrm{LMG} 784)$ and X. axonopodis pv. phaseoli (X. phaseoli) (IBSBF $1346=$ ICMP 5834 ) were inoculated onto $S$. terebinthifolius as well as onto susceptible plants of their corresponding host species. In addition, representative strains of $X$. axonopodis pv. vesicatoria (X. euvesicatoria) $($ IBSBF $345=$ ICMP 8037) and X. axonopodis pv. ricini (IBSBF $318=\mathrm{ICMP}$ 7463) were inoculated onto $M$. fistulifera as well as onto susceptible plants of their corresponding host species. Plant maintenance, inoculum preparation and inoculation were conducted as described for pathogenicity tests. Bacterial strains inoculated onto their respective host species served as positive controls for disease.

\section{Results}

\section{Disease symptoms and bacterial isolation}

On both plant species, disease symptoms were characterized by water-soaked, angular and interveinal lesions on the leaves. As the disease progressed, the lesions coalesced and ranged from brown to black, and often occupied a large portion of the leaf area (Fig. 1a,b). Leaf defoliation was observed at advanced stages of infection, and in some cases the seedlings died. Bacteria were easily isolated on solid 523 medium from disease lesions of both host species and formed bright yellow colonies after $24-48 \mathrm{~h}$ of incubation at $28^{\circ} \mathrm{C}$. Four strains recovered from S. terebinthifolius (LPF 603, LPF 604, LPF 605 and LPF 606) and five recovered from $M$. fistulifera (LPF 607, LPF 608, LPF 609, LPF 610 and LPF 611) were selected for further characterization in this study.

Inoculation of healthy host plants reproduced the disease symptoms observed under natural infection. Leaf blight symptoms were observed 10 days after inoculation (dai) of S. terebinthifolius with LPF 603 (Fig. 1c) and 7 dai of M. fistulifera with LPF 607 (Fig. 1d). At approximately 20 dai, defoliation was observed on both host species. Plants sprayed with water showed no disease symptoms. Bacterial colonies with the same morphological characteristics as those of strains initially recovered from natural infections were reisolated from inoculated plants and their identities were confirmed to complete Koch's postulates.

\section{$16 \mathrm{~S}$ rDNA sequence analysis}

To determine the taxonomic position of the strains recovered from $S$. terebinthifolius and $M$. fistulifera, their 

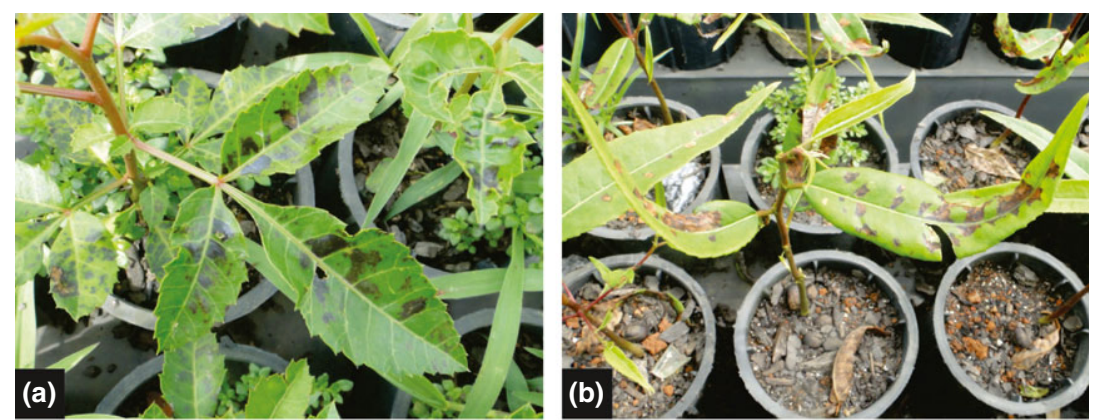

Figure 1 Symptoms of leaf blight on Schinus terebinthifolius and Mabea fistulifera. (a) Leaf blight on S. terebinthifolius seedlings caused by natural infection in nurseries, (b) leaf blight on $M$. fistulifera seedlings caused by natural infection in nurseries, (c) symptoms caused by strain LPF 603 after artificial inoculation on S. terebinthifolius, and (d) symptoms caused by strain LPF 607 after artificial inoculation on M. fistulifera. [Colour figure can be viewed at wileyonlinelibrary.com]
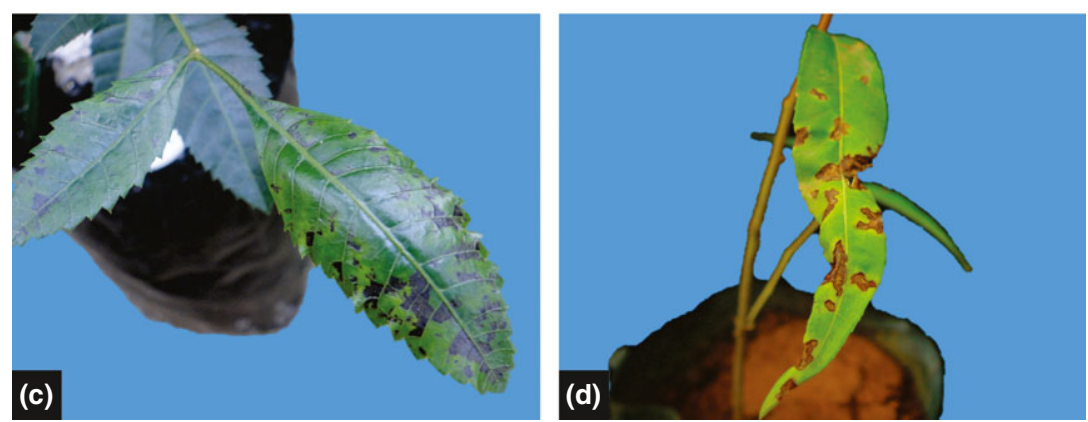

partial 16S rDNA sequences were first compared to sequences present in the NCBI nonredundant databases using BLAST. The $16 \mathrm{~S}$ rDNA sequence of LPF 603 showed higher than $99 \%$ identity with sequences of X. citri subsp. citri (GeneBank accession no. CP008989), X. axonopodis pv. glycines (KM593178) and X. campestris pv. viticola (JQ513818). The $16 \mathrm{~S}$ rDNA sequence of LPF 607 showed higher than $99 \%$ identity with the sequences of X. fuscans subsp. fuscans (FO681494), X. axonopodis pv. diffenbachiae (KM576803) and X. campestris pv. coriandri (AY601494). Therefore, LPF 603 and LPF 607 were identified as belonging to the genus Xanthomonas.

\section{Biochemical and physiological characterization}

Bacterial strains recovered from both hosts were typical of Xanthomonas spp. They were Gram-negative and formed yellow and mucilaginous colonies on YDC agar medium. They were positive for starch utilization, catalase, gelatine liquefaction, $\mathrm{H}_{2} \mathrm{~S}$ production and esculin hydrolysis. All strains produced xanthomonadin and were negative for oxidase, urease, nitrate reductase and asparaginase. They did not grow under anaerobic conditions and did not produce fluorescent pigments on King's $B$ medium.

\section{Metabolic fingerprinting}

The metabolic profile of strains recovered from both hosts determined using the Biolog system was the same as previously described for $X$. axonopodis (Vauterin et al., 1995). The only exception with the newly isolated strains was their inability to metabolize succinamic acid. Strains from S. terebinthifolius differed in the profile of carbon source utilization from strains recovered from
M. fistulifera (Table 2). Strains from S. terebinthifolius showed positive reactions for 38 carbon sources, whereas strains isolated from $M$. fistulifera were able to utilize 34 out of 95 carbon sources tested in the Biolog system (Table 2). Strains isolated from M. fistulifera (LPF 607611) had a positive reaction for all carbon sources used by $S$. terebinthifolius strains (LPF 603-606), except for acetic acid, $\alpha$-ketobutyric acid, propionic acid and L-aspartic acid.

\section{Fatty acid analysis}

Fatty acid profiles of the strains isolated from both hosts were the same as the profiles for $X$. axonopodis (Table 3) reported by Vauterin et al. (1996). The profile of strains recovered from $S$. terebinthifolius more closely resembled the profile of $X$. axonopodis pv. glycines and $X$. axonopodis pv. manibotis with similarity indices (SI) of 0.76 and 0.71 , respectively. The profiles of strains obtained from $M$. fistulifera were more similar to X. axonopodis pv. glycines $(\mathrm{SI}=0.75)$ and $X$. axonopodis pv. manihotis $(\mathrm{SI}=0.73)$. In contrast, $X$. axonopodis pv. phaseoli var. fuscans (X. fuscans subsp. fuscans) had a SI of only 0.50 .

\section{Multilocus sequence analysis}

Two phylogenetic analyses were performed. The first was to position the bacterial strains recovered from S. terebinthifolius and M. fistulifera in the genus Xanthomonas, and the second was to position them within the species $X$. axonopodis. In both phylogenetic analyses, partial sequences of $928,698,829$ and 856 bp were used for $d n a K, f y u A, g y r B$ and $r p o D$, respectively. The total length of the alignment obtained with concatenated 
Table 2 Characterization of Xanthomonas axonopodis strains based on the Biolog test

\begin{tabular}{|c|c|c|c|}
\hline Carbon source & $\begin{array}{l}\text { Schinus } \\
\text { terebinthifolius } \\
\text { (LPF 603-606) }\end{array}$ & $\begin{array}{l}\text { Mabea } \\
\text { fistulifera } \\
\text { (LPF 607-611) }\end{array}$ & $\begin{array}{l}\text { Vauterin } \\
\text { et al. } \\
(1995)^{a}\end{array}$ \\
\hline$\alpha$-cyclodextrin & - & - & - \\
\hline Dextrin & + & + & + \\
\hline Glycogen & + & + & V \\
\hline Tween 40 & + & + & V \\
\hline Tween 80 & - & - & V \\
\hline $\begin{array}{l}\mathrm{N} \text {-acetyl- } \\
\text { D-galactosamine }\end{array}$ & - & - & V \\
\hline $\begin{array}{l}\text { N-acetyl- } \\
\text { D-glucosamine }\end{array}$ & + & + & V \\
\hline Adonitol & - & - & - \\
\hline L-arabinose & - & - & V \\
\hline D-arabitol & - & - & - \\
\hline D-cellobiose & + & + & + \\
\hline meso-erythritol & - & - & - \\
\hline D-fructose & + & + & + \\
\hline L-fucose & + & + & V \\
\hline D-galactose & + & + & V \\
\hline Gentiobiose & + & + & + \\
\hline$\alpha$-D-glucose & + & + & + \\
\hline m-inositol & - & - & - \\
\hline$\alpha$-D-lactose & - & - & V \\
\hline Lactulose & + & + & V \\
\hline Maltose & + & + & + \\
\hline D-mannitol & - & - & V \\
\hline D-mannose & + & + & + \\
\hline D-melibiose & - & - & V \\
\hline$\beta$-methyl-D-glucoside & - & - & - \\
\hline D-psicose & + & + & + \\
\hline D-raffinose & - & - & V \\
\hline L-rhamnose & - & - & - \\
\hline D-sorbitol & - & - & V \\
\hline Sucrose & + & + & V \\
\hline D-trehalose & + & + & + \\
\hline Turanose & - & - & V \\
\hline Xylitol & - & - & - \\
\hline Methyl pyruvate & + & + & + \\
\hline Monomethyl succinate & + & + & + \\
\hline Acetic acid & + & - & V \\
\hline Cis-aconitic acid & + & + & V \\
\hline Citric acid & + & + & V \\
\hline Formic acid & - & - & - \\
\hline D-galactonic acid lactone & - & - & - \\
\hline D-galacturonic acid & - & - & - \\
\hline D-gluconic acid & - & - & V \\
\hline D-glucosaminic acid & - & - & - \\
\hline D-glucuronic acid & - & - & - \\
\hline$\alpha$-hydroxybutyric acid & - & - & V \\
\hline$\beta$-hydroxybutyric acid & - & - & V \\
\hline$\gamma$-hydroxybutyric acid & - & - & - \\
\hline $\begin{array}{l}\text { p-hydroxyphenylacetic } \\
\text { acid }\end{array}$ & - & - & - \\
\hline Itaconic acid & - & - & - \\
\hline$\alpha$-ketobutyric acid & + & - & V \\
\hline$\alpha$-ketoglutaric acid & + & + & + \\
\hline$\alpha$-ketovaleric acid & - & - & - \\
\hline DL-lactic acid & - & - & V \\
\hline
\end{tabular}

(continued)
Table 2 (continued)

\begin{tabular}{|c|c|c|c|}
\hline Carbon source & $\begin{array}{l}\text { Schinus } \\
\text { terebinthifolius } \\
\text { (LPF 603-606) }\end{array}$ & $\begin{array}{l}\text { Mabea } \\
\text { fistulifera } \\
\text { (LPF 607-611) }\end{array}$ & $\begin{array}{l}\text { Vauterin } \\
\text { et al. } \\
(1995)^{a}\end{array}$ \\
\hline Malonic acid & + & + & V \\
\hline Propionic acid & + & - & v \\
\hline Quinic acid & - & - & - \\
\hline D-saccharic acid & - & - & V \\
\hline Sebacic acid & - & - & - \\
\hline Succinic acid & + & + & + \\
\hline Bromosuccinic acid & + & + & + \\
\hline Succinamic acid & - & - & + \\
\hline Glucuronamide & - & - & - \\
\hline L-alaninamide & + & + & V \\
\hline D-alanine & + & + & + \\
\hline L-alanine & + & + & + \\
\hline L-alanylglycine & + & + & + \\
\hline L-asparagine & - & - & V \\
\hline L-aspartic acid & + & - & v \\
\hline L-glutamic acid & + & + & + \\
\hline Glycyl-L-aspartic acid & - & - & v \\
\hline Glycyl-L-glutamic acid & + & + & + \\
\hline L-histidine & - & - & V \\
\hline Hydroxy-L-proline & + & + & v \\
\hline L-leucine & - & - & V \\
\hline L-ornithine & - & - & v \\
\hline L-phenylalanine & - & - & - \\
\hline L-proline & + & + & v \\
\hline L-pyroglutamic acid & - & - & - \\
\hline D-serine & - & - & - \\
\hline L-serine & + & + & v \\
\hline L-threonine & - & - & V \\
\hline DL-carnitine & - & - & - \\
\hline$\gamma$-aminobutyric acid & - & - & - \\
\hline Urocanic acid & - & - & v \\
\hline Inosine & - & - & v \\
\hline Uridine & - & - & v \\
\hline Thymidine & - & - & - \\
\hline Phenyethylamine & - & - & - \\
\hline Putrescine & - & - & - \\
\hline 2-aminoethanol & - & - & - \\
\hline 2,3-butanediol & - & - & - \\
\hline Glycerol & + & + & V \\
\hline DL- $\alpha$-glycerol phosphate & - & - & v \\
\hline Glucose-1-phosphate & - & - & V \\
\hline Glucose-6-phosphate & - & - & V \\
\hline
\end{tabular}

aStrains of $X$. axonopodis used by Vauterin et al. (1995):,$+ \geq 90 \%$ of strains are positive;,$- \geq 90 \%$ of strains are negative; $V, 11-89 \%$ of strains were able to metabolize the carbon source.

sequences of the four genes was $3311 \mathrm{bp}$. In the first phylogenetic analysis, including multiple Xanthomonas species, the number of conserved sites was $705,471,416$ and 504 and the number of variable sites was 223,227 , 413 and 351 for dnaK, fyuA, gyrB and $r p o D$, respectively. The number of parsimony informative sites was 92, 152, 248 and 230 for $d n a K, f y u A, g y r B$ and $r p o D$, respectively. The best evolutionary model selected by MrModeltest v. 2.3 for Bayesian analysis by AIC was the general time reversible plus invariant site plus gamma 
Table 3 Summary of the fatty acid composition of strains from Schinus terebinthifolius (LPF 603-606) and Mabea fistulifera (LPF 607-611)

\begin{tabular}{|c|c|c|}
\hline Compound & S. terebinthifolius & M. fistulifera \\
\hline \multicolumn{3}{|l|}{ Saturated fatty acids } \\
\hline $10: 0$ & $1.09 \pm 0.09$ & $1.10 \pm 0.17$ \\
\hline $14: 0$ & $1.90 \pm 0.22$ & $2.04 \pm 0.24$ \\
\hline $16: 0$ & $6.70 \pm 0.52$ & $6.96 \pm 0.39$ \\
\hline $17: 0$ & $0.18 \pm 0.01$ & $0.10 \pm 0.00^{\circ}$ \\
\hline \multicolumn{3}{|l|}{ Unsaturated fatty acids } \\
\hline $15: 1$ w6c & $0.58 \pm 0.05$ & $0.32 \pm 0.02$ \\
\hline $16: 1 w 7 c / 16: 1 w 6 c$ & $23.56 \pm 1.45$ & $25.07 \pm 1.51$ \\
\hline $16: 1 w 5 c$ & $0.16 \pm 0.03^{a}$ & $0.12 \pm 0.04^{b}$ \\
\hline $16: 010$-methyl/17:1 iso w9c & $4.24 \pm 0.34$ & $4.27 \pm 0.51$ \\
\hline $17: 1$ w8c & $1.39 \pm 0.09$ & $0.90 \pm 0.06$ \\
\hline $17: 1 w 6 c$ & $0.26 \pm 0.01$ & $0.19 \pm 0.01$ \\
\hline $18: 1 w 9 c$ & $0.57 \pm 0.03$ & $0.61 \pm 0.03$ \\
\hline $18: 1$ w7c/18:1 w6c & $0.76 \pm 0.05$ & $0.68 \pm 0.03$ \\
\hline \multicolumn{3}{|l|}{ Hydroxy fatty acids } \\
\hline $10: 03 \mathrm{OH}$ & $0.41 \pm 0.03$ & $0.42 \pm 0.04$ \\
\hline $10: 02 \mathrm{OH}$ & $0.21 \pm 0.03$ & $0.21 \pm 0.03$ \\
\hline $11: 03 \mathrm{OH}$ & $0.35 \pm 0.01$ & $0.24 \pm 0.01$ \\
\hline $12: 03 \mathrm{OH}$ & $4.08 \pm 0.31$ & $4.03 \pm 0.60$ \\
\hline $16: 03 \mathrm{OH}$ & $0.17 \pm 0.04$ & $0.20 \pm 0.06$ \\
\hline \multicolumn{3}{|l|}{ Branched-chain fatty acids } \\
\hline $11: 0$ iso & $4.32 \pm 0.26$ & $4.00 \pm 0.16$ \\
\hline $13: 0$ iso & $0.28 \pm 0.01$ & $0.26 \pm 0.01$ \\
\hline $14: 0$ iso & $0.27 \pm 0.01$ & $0.27 \pm 0.01$ \\
\hline $15: 0$ iso & $27.83 \pm 0.69$ & $27.25 \pm 0.87$ \\
\hline 15:0 anteiso & $5.53 \pm 0.41$ & $6.53 \pm 0.41$ \\
\hline $16: 0$ iso & $1.04 \pm 0.07$ & $1.06 \pm 0.10$ \\
\hline $17: 0$ iso & $6.77 \pm 0.48$ & $6.15 \pm 0.63$ \\
\hline $17: 0$ anteiso & $0.30 \pm 0.03$ & $0.35 \pm 0.04$ \\
\hline \multicolumn{3}{|c|}{ Branched-chain unsaturated fatty acids } \\
\hline $15: 1$ iso $F$ & $0.23 \pm 0.02$ & $0.27 \pm 0.05$ \\
\hline \multicolumn{3}{|c|}{ Branched-chain hydroxy fatty acids } \\
\hline $12: 0$ iso $3 \mathrm{OH}$ & $0.18 \pm 0.01^{a}$ & $0.18 \pm 0.01^{\mathrm{C}}$ \\
\hline $17: 0$ iso $30 \mathrm{H}$ & $0.29 \pm 0.02$ & $0.28 \pm 0.03$ \\
\hline
\end{tabular}

${ }^{\text {a}}$ Fatty acid is absent in one strain.

${ }^{\mathrm{b}}$ Fatty acid absent in two strains.

${ }^{\mathrm{c}}$ Fatty acid absent in three strains.

$(\mathrm{GTR}+\mathrm{I}+\mathrm{G})$ for all four genes included in this species-level analysis. The results indicate that strains recovered from both plant species cluster together with $X$. axonopodis (Fig. 2).

In the second phylogenetic analysis, which included several species and pathovars of $X$. axonopodis, the numbers of conserved and variable sites were 843 and 87 for dnaK, 572 and 126 for fyuA, 672 and 158 for gyrB, and 750 and 107 for $r p o D$, respectively. The number of parsimony informative sites was 58 for dnaK, 59 for $f y u A, 69$ for $g y r B$, and 54 for $r p o D$. In this case, MrModeltest v. 2.3 selected the GTR $+G$ model for all genes, except $d n a K$, for which the best fit was the GTR + I + G model. The results showed the strains recovered from S. terebinthifolius (LPF 603-606) grouped together in RG 9.4 (Rademaker et al., 2005) and were phylogenetically more closely related to $X$. axonopodis pv. manihotis and X. axonopodis pv. phaseoli
(X. phaseoli, Gabriel et al., 1989). Strains recovered from M. fistulifera (LFP 607-611) grouped together in RG 9.2 (Rademaker et al., 2005) and were more closely related to $X$. axonopodis pv. vesicatoria (X. euvesicatoria, Jones et al., 2004), X. axonopodis pv. ricini, X. axonopodis pv. alfalfae (X. alfalfae, Schaad et al., 2006), $X$. axonopodis pv. citrumelo (X. alfalfae subsp. citrumelonis, Schaad et al., 2006) and X. perforans (Jones et al., 2004) (Fig. 3).

\section{Plant cross-inoculations}

Taken together, the results of the MLSA and fatty acid profiling indicated that the newly isolated strains were more closely related to $X$. axonopodis pv. manihotis, $X$. axonopodis pv.phaseoli (X.phaseoli), X. axonopodis pv. vesicatoria (X. euvesicatoria) and X. axonopodis pv. ricini, but no study has reported that any of these pathovars were able to cause disease on S. terebinthifolius and/or M. fistulifera. Therefore, it was decided to inoculate susceptible host plants with their cognate pathovars as well as with LPF 603 and LPF 607. Mabea fistulifera and S. terebinthifolius were also inoculated with each bacterial strain that was tested. All strains belonging to previously reported pathovars caused disease on their respective host species, but did not cause disease on M. fistulifera or on S. terebinthifolius. LPF 603 caused disease only on M. fistulifera whereas LPF 607 was able to infect only S. terebinthifolius (Table 4). These results indicate that the strains newly isolated from $M$. fistulifera and S. terebinthifolius belong to two pathovars that have not been previously reported.

\section{Discussion}

In an attempt to identify the causal agents responsible for leaf blight observed on M. fistulifera and S. terebinthifolius during an inspection of a nursery in the Brazilian state of Minas Gerais, yellow-pigmented bacteria were isolated, from which the disease symptoms could be reproduced by inoculation into healthy plants and completing Koch's postulates. Based on physiological and biochemical tests as well as the sequence of their $16 \mathrm{~S}$ rDNA region, the newly isolated strains were tentatively identified to be xanthomonads. The strains could not be assigned to a defined species within Xanthomonas either by comparison of the $16 \mathrm{~S}$ rDNA sequences with sequences deposited in the databases or from the results of the biochemical and physiological tests (Hauben et al., 1997).

Metabolic fingerprinting showed that all strains isolated in this study were able to utilize the same carbon sources as previously described for $X$. axonopodis (Vauterin et al., 1995). Additionally, fatty acid profiles were most similar to profiles of other pathovars of the species $X$. axonopodis. Nevertheless, it was not possible to conclusively assign the newly isolated strains to any pathovar. 


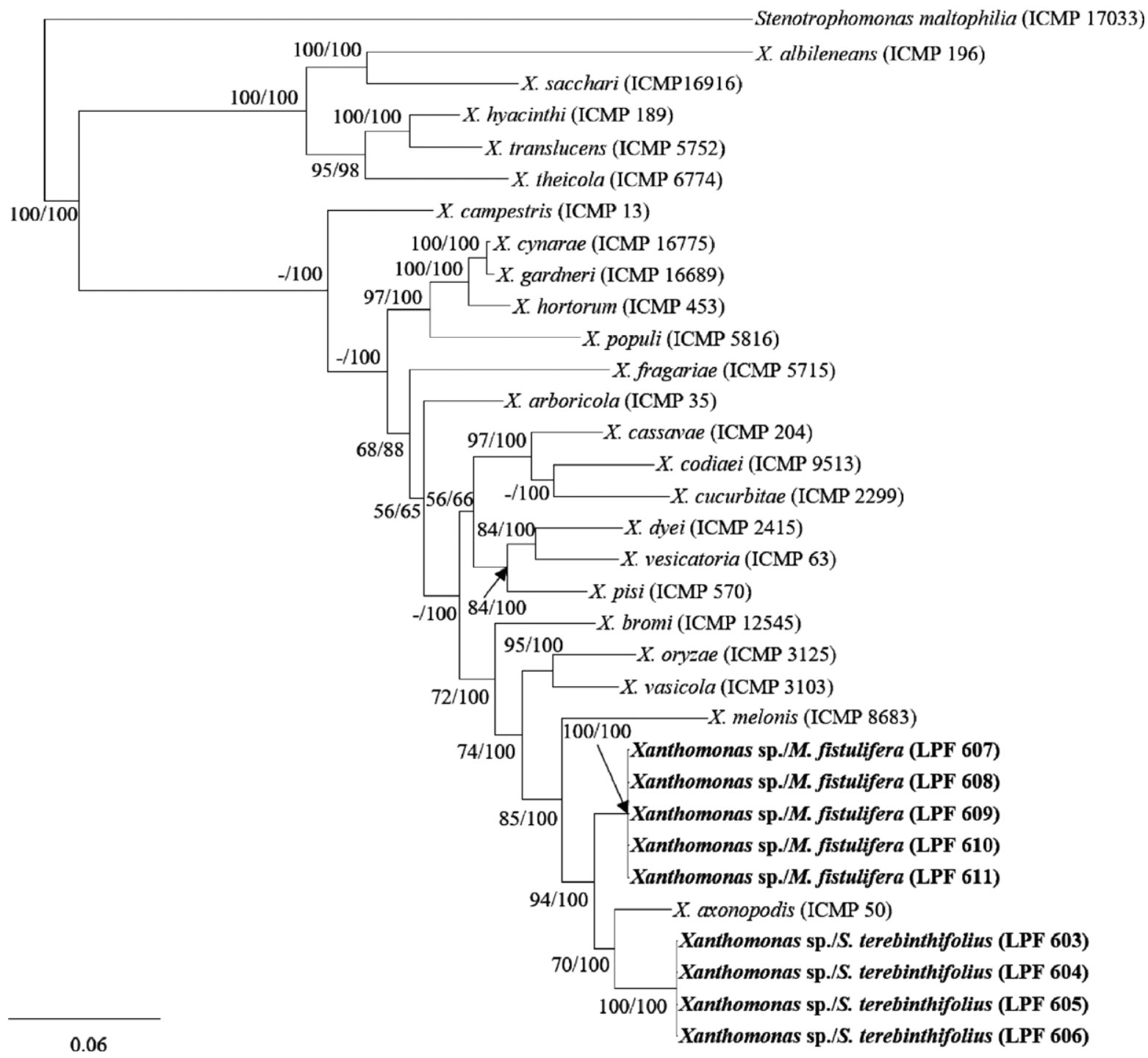

Figure 2 Phylogenetic tree of concatenated dnaK, fyuA, gyrB and rpoD partial nucleotide sequences constructed by Bayesian inference. Bootstrap values are indicated above the branches while posterior probabilities are indicated after the slashes. Bar indicates the fraction of substitutions per site. The Xanthomonas species included in this analysis are the same as those included in Young et al. (2008). Stenotrophomonas maltophilia (ICMP 17033) is used as an out-group.

MLSA was then used to delimit the strains isolated from S. terebinthifolius and M. fistulifera within X. axonopodis. Strains isolated from S. terebinthifolius clustered in group RG 9.4 (Rademaker et al., 2005) along with the $X$.axonopodis pv. manihotis and $X . a x-$ onopodis pv. phaseoli (X. phaseoli) and strains from M. fistulifera grouped in RG 9.2 along with pathovars $X$. axonopodis pv. ricini and $X$. axonopodis pv. vesicatoria (X. envesicatoria). Rademaker et al. (2005) previously showed that the species $X$. axonopodis could be divided into groups (RG) 9.1-9.6 based on rep-PCR analysis. Group RG 9.2 was composed of a large number of pathovars including alfalfae (X. alfalfae subsp. alfalfae), cassavae, cassiae, citrumelo (X. alfalfae pv. citrumelonis), coracanae, cyamopsidis, desmodii, desmodiigangetici, desmodiirotundifolii, erythrinae, lespedezae, patelii, phyllanthi, poinsettiicola, ricini, tamarindi and vesicatoria (X. euvesicatoria); while RG 9.4 included pathovars manihotis, phaseoli and dieffenbachiae (Rademaker et al., 2005). Other studies have proposed the reclassification of several pathovars of group RG 9.2 to the species level based on results of more recent DNA-DNA reassociation. Jones et al. (2004) proposed the reclassification of phenotypic groups $\mathrm{A}$ and $\mathrm{C}$ of $\mathrm{X}$. axonopodis pv. vesicatoria to the species $X$. envesicatoria and X. gardneri, respectively. Similarly, $X$. axonopodis pv. alfalfae was reclassified to X. alfalfae subsp. alfalfae (Schaad et al., 2005, 2006). It was also proposed to reclassify the fuscans variant of X. axonopodis to X. fuscans subsp. fuscans (Schaad et al., 


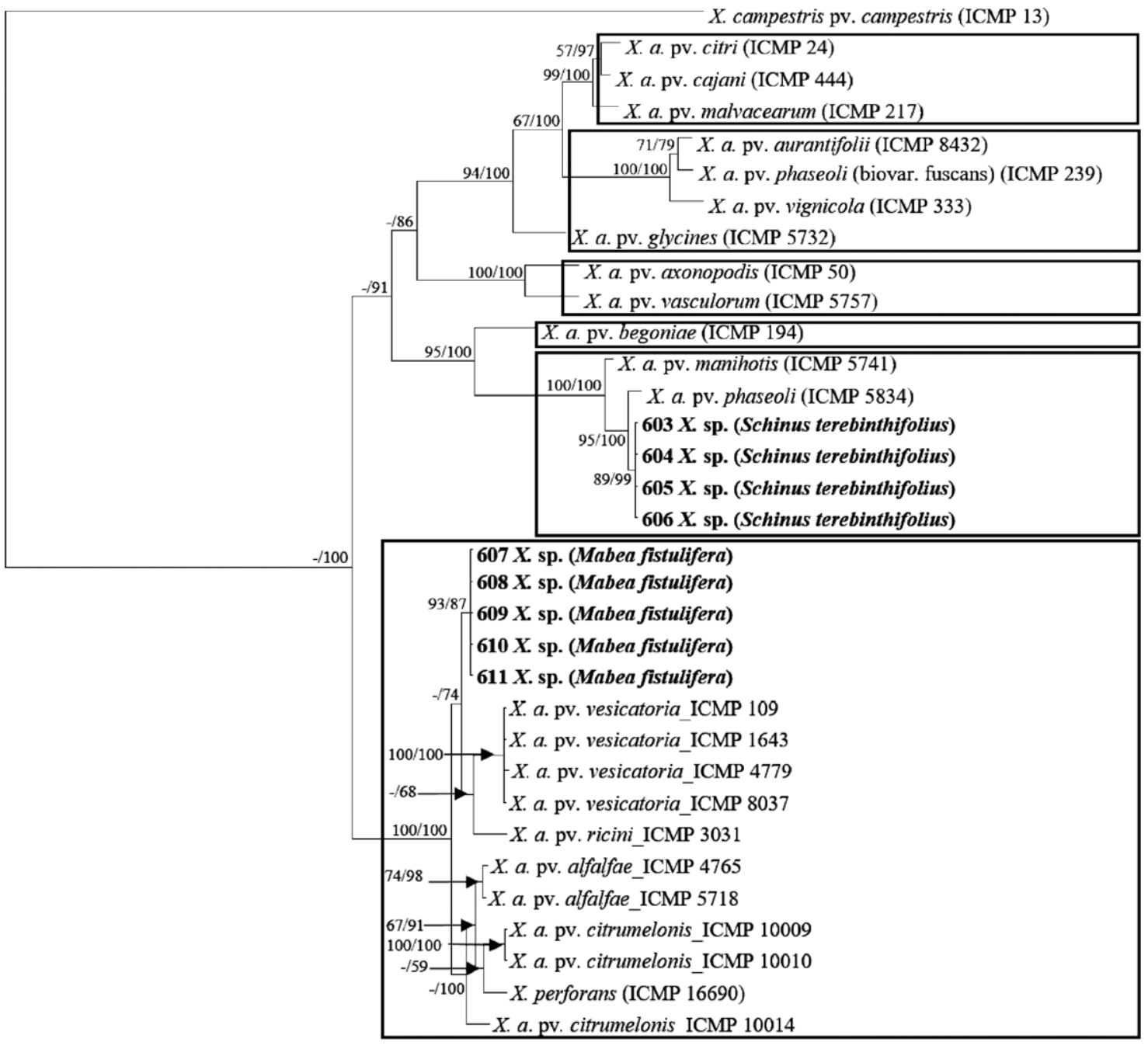

Figure 3 Phylogenetic tree of concatenated dnaK, fyuA, gyrB and rpoD partial nucleotide sequences constructed by Bayesian inference. Bootstrap values are indicated above the branches while posterior probabilities are indicated after the slashes. Xanthomonas axonopodis ( $X$. a.) pathovars are grouped according to Rademaker et al. (2005). The bar indicates the number of substitutions per site. Xanthomonas campestris pv. campestris (ICMP 13) is used as an out-group.

2005, 2006). Xanthomonas citri subsp. citri and X. citri subsp. malvacearum have been validly published (Gabriel et al., 1989). According to Bull et al. (2010), there are currently at least 41 validly published names for pathovars of $X$. axonopodis. In this study, the taxonomic classification and nomenclature widely accepted and used by Vauterin et al. (1995) and Rademaker et al. (2005) was adopted to assign a taxonomic position to the pathogenic strains isolated from $S$. terebinthifolius and M. fistulifera within the genus Xanthomonas. Overall, the results suggested that strains isolated from these plant species belonged to two newly defined $X$. axonopodis pathovars.

To position strains from $M$. fistulifera and $S$. terebinthifolius into specific pathovars within $X$. axonopodis, the sequences of four housekeeping genes were compared with sequences of well-characterized
$X$. axonopodis pathovars. Strains isolated from M. fistulifera were found to be more closely related to the pathovars vesicatoria (X. euvesicatoria) and ricini, and those isolated from $S$. terebinthifolius were more closely related to pathovars manihotis and phaseoli (X. phaseoli, Gabriel et al., 1989). However, no X. axonopodis pathovar has been reported to cause disease on M. fistulifera. On the other hand, there was one report indicating that $S$. terebinthifolius could be an alternate host for X. campestris pv. viticola, which is the causal agent of bacterial canker in grapevine (Peixoto et al., 2007). Additionally, pathovars mangiferaeindicae, anacardii and spondiae are pathogenic to some members of the family Anacardiaceae. These pathovars can also infect S. terebinthifolius, which belongs to the same botanical family (Ah-You et al., 2007), but only X. axonopodis 


\begin{tabular}{|c|c|c|c|c|c|c|c|c|}
\hline \multirow[b]{2}{*}{ Pathogen } & \multirow[b]{2}{*}{ Strain } & \multirow[b]{2}{*}{ Source plant } & \multicolumn{6}{|l|}{ Inoculated plant } \\
\hline & & & $\begin{array}{l}\text { Schinus } \\
\text { terebinthifolius }\end{array}$ & $\begin{array}{l}\text { Mabea } \\
\text { fistulifera }\end{array}$ & $\begin{array}{l}\text { Capsicum } \\
\text { annuum }\end{array}$ & $\begin{array}{l}\text { Manihot } \\
\text { esculenta }\end{array}$ & $\begin{array}{l}\text { Phaseolus } \\
\text { vulgaris }\end{array}$ & $\begin{array}{l}\text { Ricinus } \\
\text { communis }\end{array}$ \\
\hline $\begin{array}{l}\text { Xanthomonas } \\
\text { axonopodis }\end{array}$ & LPF 603 & S. terebinthifolius & + & - & ND & - & - & ND \\
\hline$X$. axonopodis & LPF 607 & M. fistulifera & - & + & - & ND & ND & - \\
\hline $\begin{array}{l}X . \text { axonopodis } \\
\text { pv. vesicatoria }\end{array}$ & $\begin{array}{l}\text { IBSBF 345/ICMP } \\
8037\end{array}$ & C. annuum & ND & - & + & ND & ND & ND \\
\hline $\begin{array}{l}X . \text { axonopodis } \\
\text { pv. manihotis }\end{array}$ & $\begin{array}{c}\text { IBSBF 278/ICMP } \\
\text { 5741/LMG } 784\end{array}$ & M. esculenta & - & ND & ND & + & ND & ND \\
\hline $\begin{array}{l}\text { X. axonopodis } \\
\text { pv. phaseoli }\end{array}$ & $\begin{array}{l}\text { IBSBF 2930/ATCC } \\
\text { 9563/NCPPB } \\
\text { 3035/LMG } \\
\text { 7455/CFBP } 2534\end{array}$ & P. vulgaris & - & ND & ND & ND & + & ND \\
\hline $\begin{array}{l}\text { X.axonopodis } \\
\text { pv. ricini }\end{array}$ & $\begin{array}{l}\text { IBSBF 2939/ICMP } \\
5747\end{array}$ & R. communis & ND & - & ND & ND & ND & + \\
\hline
\end{tabular}

+, Disease symptoms; -, no symptoms; ND, not determined.

pv. mangiferaeindicae was found to naturally cause disease on S. terebinthifolius (Pruvost et al., 1992). Pathovars mangiferaeindicae and anacardii belong to RG 9.5 and RG 9.6, respectively (Ah-You et al., 2007), which ruled out the possibility that the strains isolated from S. terebinthifolius in this study, which clustered in RG 9.4, belong to either of these two pathovars. Furthermore, $X$. axonopodis pv. spondiae, which causes leaf spots on mombins (Spondias dulcis), belongs to the same $\mathrm{RG}$ as the strains isolated from $S$. terebinthifolius. However, colonies of $X$. axonopodis pv. spondiae are white (atypical of a xanthomonad), whereas the strains recovered from S. terebinthifolius are yellow. Moreover, $X$. axonopodis pv. spondiae has only been reported in the French Antilles (Ah-You et al., 2007). Those strains isolated from $M$. fistulifera or S. terebinthifolius failed to cause disease on C. annuum, M. esculenta, $P$. vulgaris or $R$. communis, which therefore rules out the possibility that they belong to the previously reported pathovars vesicatoria (X. envesicatoria), manibotis, phaseoli (X. phaseoli) or ricini. Furthermore, strains representative of these pathovars did not cause disease on either M. fistulifera or S. terebinthifolius. The reproduction of disease symptoms only in their respective source plant species indicated that these bacteria showed host specificity and belonged to different pathovars.

The polyphasic approach used in this study was a robust method for bacterial taxonomy (Young et al., 2008; Samanta et al., 2013). This approach encompassed morphological, physiological, biochemical, molecular and pathogenic characterization of the bacterial strains recovered from S. terebinthifolius and M. fistulifera. Comparisons of the results of these analyses with other xanthomonads revealed that they were not identical to any other pathovar that has been previously reported, and most importantly, they were distinctively pathogenic in the plant species from which they were isolated. Consequently, two new pathovars, $X$. axonopodis pv. schini pv. nov. infecting S. terebinthifolius and X. axonopodis pv. mabeae pv. nov. infecting $M$. fistulifera are proposed and described in this study.

\section{Description of Xanthomonas axonopodis pv. schini pv. nov}

Xanthomonas axonopodis pv. schini (shi'ni. N.L. gen. n. schini of Schinus, referring to the isolation source of the type strain).

The phenotypic description of the pathovar is based on representative strain LPF 603. The cells are Gramnegative and form yellow and mucilaginous colonies with abundant slime formation on YDC medium. The strains were positive for starch utilization, catalase, gelatine liquefaction, $\mathrm{H}_{2} \mathrm{~S}$ production and esculin hydrolysis. They produced xanthomonadin on NA medium; were negative for oxidase, urease, nitrate reductase; did not grow under anaerobic conditions; and did not produce fluorescent pigments on King's B medium. They were not able to utilize asparagine as a sole source of carbon and nitrogen.

The strains had positive auxanographic reactions for dextrin, glycogen, Tween 40, N-acetyl-D-glucosamine, Dcellobiose, D-fructose, L-fucose, D-galactose, gentiobiose, $\alpha$-D-glucose, lactulose, maltose, D-mannose, D-psicose, sucrose, D-trehalose, methyl pyruvate, monomethyl-succinate, acetic acid, cis-aconitic acid, citric acid, $\alpha$-ketobutyric acid, $\alpha$-ketoglutaric acid, malonic acid, propionic acid, succinic acid, bromosuccinic acid, L-alaninamide, D-alanine, L-alanine, L-alanylglycine, L-aspartic acid, L-glutamic acid, glycyl-L-glutamic acid, hydroxy-L-proline, L-proline, L-serine and glycerol. Negative reactions were observed for $\alpha$-cyclodextrin, Tween $80, N$-acetyl-D-galactosamine, adonitol, L-arabinose, D-arabitol, meso-erythritol, $m$-inositol, $\alpha$-D-lactose, D-mannitol, $\beta$-methyl-D-glucoside, D-raffinose, L-rhamnose, D-sorbitol, turanose, xylitol, formic acid, D-galactonic acid lactone, D-galacturonic acid, D- 
gluconic acid, D-glucosaminic acid, D-glucuronic acid, $\alpha$ hydroxybutyric acid, $\beta$-hydroxybutyric acid, $\gamma$-hydroxybutyric acid, $p$-hydroxyphenylacetic acid, itaconic acid, $\alpha$-ketovaleric acid, DL-lactic acid, quinic acid, D-saccharic acid, sebacic acid, succinamic acid, glucuronamide, L-asparagine, glycyl-L-aspartic acid, L-histidine, L-leucine, L-ornithine, L-phenylalanine, L-pyroglutamic acid, D-serine, L-threonine, DL-carnitine, $\gamma$-aminobutyric acid, urocanic acid, inosine, uridine, thymidine, phenyethylamine, putrescine, 2-aminoethanol, 2,3-butanediol, DL- $\alpha$-glycerol phosphate, glucose-1-phosphate and glucose-6-phosphate.

The type strain is LPF 603, which caused bacterial leaf blight on Schinus terenbithifolius and was isolated from infected tissue in the municipality of Viçosa in the state of Minas Gerais, Brazil. GenBank accession numbers of the $16 \mathrm{~S}$ rDNA, dnaK, fyuA, gyrB and $r p o D$ sequences of the type strain are KY271338, KY205644, KY205653, KY273415 and KY273424, respectively.

\section{Description of $X$. axonopodis pv. mabeae pv. nov}

Xanthomonas axonopodis pv. mabeae (ma.be'ae. N.L. gen. n. mabeae of Mabea, referring to the isolation source of the type strain).

The phenotypic description of the pathovar is based on representative strain LPF 607. Cells exhibited the same morphological, physiological and biochemical characteristics as the cells described above for pathovar schini, except they showed negative auxotrophic reactions for acetic acid, $\alpha$-ketobutyric acid, propionic acid and L-aspartic acid. This pathovar also differs from pathovar schini because of its distinctive pathogenicity on M. fistulifera and not on S. terebinthifolius.

The type strain is LPF 607, which caused bacterial leaf blight on $M$. fistulifera and was isolated from infected tissue in the municipality of Viçosa in the state of Minas Gerais, Brazil. GenBank accession numbers of the $16 \mathrm{~S}$ rDNA, dnaK, fyuA, gyrB and rpoD sequences of the type strain are KY287944, KY205648, KY205657, KY273419 and KY273428, respectively.

\section{Acknowledgements}

The authors are grateful to the biotechnological company Clonar Resistência a Doenças Florestais for providing the plant material and the inoculation facilities and to FAPEMIG and CNPq for financial support.

\section{References}

Ah-You N, Gagnevin L, Chiroleu F, Jouen E, Neto JR, Pruvost O, 2007. Pathological variations within Xanthomonas campestris pv. mangiferaeindicae support its separation into three distinct pathovars that can be distinguished by amplified fragment length polymorphism. Phytopathology 97, 1568-77.

Ah-You N, Gagnevin L, Grimont PAD et al., 2009. Polyphasic characterization of xanthomonads pathogenic to members of the Anacardiaceae and their relatedness to species of Xanthomonas. International Journal of Systematic and Evolutionary Microbiology 59, 306-18.
Almeida NF, Yan S, Cai R et al., 2010. PAMDB, a multilocus sequence typing and analysis database and website for plant-associated microbes. Phytopathology 100, 208-15.

Bull CT, De Boer SH, Denny TP et al., 2010. Comprehensive list of names of plant pathogenic bacteria, 1980-2007. Journal of Plant Pathology 92, 551-92.

Bull CT, De Boer SH, Denny TP et al., 2012. Letter to the editor. List of new names of plant pathogenic bacteria (2008-2010). Journal of Plant Pathology 94, 21-7.

Carvalho M, Melo A, Aragão C, Raffin FN, Moura TFAL, 2013. Schinus terebinthifolius Raddi: chemical composition, biological properties and toxicity. Revista Brasileira de Plantas Medicinais 15, 158-69.

Dye DW, 1962. The inadequacy of the usual determinative tests for the identification of Xanthomonas spp. New Zealand Journal of Science 5, 393-416.

Ewe SML, Sternberg LSL, 2002. Seasonal water-use by the invasive exotic, Schinus terebinthifolius, in native and disturbed communities. Oecologia 133, 441-8.

Furtado GQ, Guimarães LMS, Lisboa DO et al., 2012. First report of Enterobacter cowanii causing bacterial spot on Mabea fistulifera, a native forest species in Brazil. Plant Disease 96, 1576.

Gabriel DW, Kingsley MT, Hunter JE, Gottwald T, 1989. Reinstatement of Xanthomonas citri (ex Hasse) and X. phaseoli (ex Smith) to species and reclassification of all $X$. campestris pv. citri strains. International Journal of Systematic Bacteriology 39, 14-22.

Hauben L, Vauterin L, Swings J, Moore ER, 1997. Comparison of 16S ribosomal DNA sequences of all Xanthomonas species. International Journal of Systematic Bacteriology 47, 328-35.

Jones JB, Lacy GH, Bouzar H, Stall RE, Schaad NW, 2004.

Reclassification of the xanthomonads associated with bacterial spot disease of tomato and pepper. Systematic and Applied Microbiology 27, 755-62.

Kado CI, Heskett MG, 1970. Selective media for isolation of Agrobacterium, Corynebacterium, Erwinia, Pseudomonas, and Xanthomonas. Phytopathology 60, 969-76.

Leal Filho N, Borges EEL, 1992. Influência da temperatura e da luz na germinação de sementes de canudo de pito (Mabea fistulifera Mart.). Revista Brasileira de Sementes 14, 57-60.

Morton JF, 1978. Brazilian pepper - its impact on people, animals and the environment. Economic Botany 32, 353-9.

Peixoto AR, Mariano RLR, Moreira JOT, Viana IO, 2007. Hospedeiros alternativos de Xanthomonas campestris pv. viticola. Fitopatologia Brasileira 32, 161-4.

Pruvost O, Couteau A, Luisetti J, 1992. Pepper tree (Schinus terebenthifolius Radii) a new host plant for Xanthomonas campestris pv. mangiferaeindicae. Journal of Phytopathology 135, 289-98.

Rademaker JLW, Louws FJ, Schultz MH et al., 2005. A comprehensive species to strain taxonomic framework for Xanthomonas. Phytopathology 95, 1098-111.

Ronquist F, Huelsenbeck JP, 2003. MRBAYEs 3: Bayesian phylogenetic inference under mixed models. Bioinformatics 19, 1572-4.

Samanta JN, Mandal K, Maiti S, 2013. A novel pathovar of Xanthomonas axonopodis causes gumming of Guggal (Commiphora wightii). European Journal of Plant Pathology 135, 115-25.

Schaad NW, Jones JB, Chun W, 2001. Laboratory Guide for Identification of Plant Pathogenic Bacteria. St Paul, MN, USA: American Phytopathological Society.

Schaad NW, Postnikova E, Lacy GH et al., 2005. Reclassification of Xanthomonas campestris pv. citri (ex Hasse 1915) Dye 1978 forms A, $\mathrm{B} / \mathrm{C} / \mathrm{D}$, and $\mathrm{E}$ as X. smithii subsp. citri (ex Hasse) sp. nov. nom. rev. comb. nov., X. fuscans subsp. aurantifolii (ex Gabriel 1989) sp. nov. nom. rev. comb. nov., and X. alfalfae subsp. citrumelo (ex Riker and Jones) Gabriel et al., 1989 sp. nov. nom. rev. comb. nov.; X. campestris pv. malvacearum (ex Smith 1901) Dye 1978 as X. smithii subsp. smithii nov. comb. nov. nom. nov.; X. campestris pv. alfalfae (ex Riker and Jones, 1935) Dye 1978 as X. alfalfae subsp. alfalfae (ex Riker et al., $1935)$ sp. nov. nom. rev.; and 'var. fuscans' of X. campestris pv. phaseoli 
(ex Smith, 1987) Dye 1978 as X. fuscans subsp. fuscans sp. nov. Systematic and Applied Microbiology 28, 494-518.

Schaad NW, Postnikova E, Lacy G et al., 2006. Emended classification of xanthomonad pathogens on citrus. Systematic and Applied Microbiology 29, 690-5.

Trébaol G, Gardan L, Manceau C, Tanguy JL, Tirilly Y, Boury S, 2000. Genomic and phenotypic characterization of Xanthomonas cynarae sp. nov., a new species that causes bacterial bract spot of artichoke (Cynara scolymus L.). International Journal of Systematic and Evolutionary Microbiology 50, 1471-8.

Van den Mooter M, Swings J, 1990. Numerical analysis of 295 phenotypic features of 266 Xanthomonas strains and related strains and an improved taxonomy of the genus. International Journal of Systematic Bacteriology 40, 348-69.

Vauterin L, Hoste B, Kersters K, Swings J, 1995. Reclassification of Xanthomonas. International Journal of Systematic Bacteriology 45, 472-89.
Vauterin L, Yang P, Swings J, 1996. Utilization of fatty acid methyl esters for the differentiation of new Xanthomonas species. International Journal of Systematic Bacteriology 46, 298-304.

Weisburg WG, Barns SM, Pelletier DA, Lane DJ, 1991. 16 S ribosomal DNA amplification for phylogenetic study. Journal of Bacteriology 173, 697-703.

Williams DA, Overholt WA, Cuda JP, Hughes CR, 2005. Chloroplast and microsatellite DNA diversities reveal the introduction history of Brazilian peppertree (Schinus terebinthifolius) in Florida. Molecular Ecology 14, 3643-56.

Young JM, Park DC, Shearman HM, Fargier E, 2008. A multilocus sequence analysis of the genus Xanthomonas. Systematic and Applied Microbiology 31, 366-77.

Young JM, Wilkie JP, Park DC, Watson DRW, 2010. New Zealand strains of plant pathogenic bacteria classified by multi-locus sequence analysis; proposal of Xanthomonas dyei sp. nov. Plant Pathology 59, $270-81$. 